\title{
STADIA PERKEMBANGAN KABUPATEN GRESIK
}

\author{
Gratia Ananda Sinaga ${ }^{1}$, Karina Pradinie Tucunan ${ }^{2}$ \\ ${ }^{1}$ Perencanaan Wilayah dan Kota, Institut Teknologi Sepuluh Nopember \\ email: gratiananda@gmail.com \\ 2 Perencanaan Wilayah dan Kota, Institut Teknologi Sepuluh Nopember \\ email: kp.tucunan@gmail.com
}

\begin{abstract}
Abstrak
Kabupaten Gresik memiliki potensi berupa benda arkeologi yang mendorong Kabupaten Gresik sebagai Kota Pusaka. Rencana ini juga didukung oleh regulasi, komunitas masyarakat dan konsep yang ada. Namun, terdapat gap antara dukungan ini dengan kondisi eksisting benda arkeologi tersebut. Penelitian ini dilakukan untuk menyusun stadia perkembangan Kabupaten Gresik untuk mendukung Gresik sebagai Kota Pusaka. Untuk menyusun stadia, dibuat hipotesis dan kerangka stadia dengan studi literature. Lalu benda arkeologi yang dirangkum diklasifikasikan dan dinilai melalui Focus Group Discussion dengan expert yaitu ahli sejarah dan Dinas terkait. Kemudian dilakukan klarifikasi terhadap hipotesis stadia dan penilaian melalui in depth interview dengan expert dan setelah dianalisis ditemukan stadia utama perkembangan Kabupaten Gresik. Berdasarkan penelitian, diperoleh perkembangan Kabupaten Gresik dalam 5 era yaitu Majapahit, Perkembangan Islam Nusantara, Kolonial, Pendudukan Jepang dan Awal Kemerdekaan hingga kini. Dari kelima era, Perkembangan Islam Nusantara adalah era yang paling berpengaruh dalam membentuk identitas Kabupaten Gresik hingga seperti sekarang ini.
\end{abstract}

Kata Kunci: Gresik, Kota Pusaka, Perkembangan Kota, Stadia

\begin{abstract}
Gresik has the potential in the form of archaeological objects that encourage Gresik to become Heritage City. This plan is also supported by regulations, social communities, and existing concepts. However, there is a gap between this support and the existing conditions of the archaeological object. This research was conducted to conclude the historical development study of Gresik to support Gresik as a Heritage City. That one may compile the stage, hypotheses, and stadia frameworks were made using literature studies with synchronic method. Afterward, archaeological objects summarized are classified and assessed through Focus Group Discussion with the experts. Then, stage hypotheses clarification and assessment are done through in-depth interviews with experts and after analysis, the main stages of development in Gresik discovered. Based on the research, the development of Gresik was obtained in 5 eras namely Majapahit Era, Era of Spreading Islam in the Archipelago, Colonialism Era, Japanese Colonialism Era, and Early Independence Era until now. Out of the five eras, Spreading Islam in the Archipelago is the most influential era in shaping the identity of Gresik as it is today.
\end{abstract}

Keywords: , Gresik, Heritage City, Morphological Study 


\section{PENDAHULUAN}

Kabupaten Gresik memiliki berbagai potensi daya tarik, diantara berbagai potensi tersebut salah satu potensi yang utama adalah peninggalan sejarah yaitu 8 situs makam. Selain itu, terdapat Kampung Kemasan yang merupakan potensi heritage skala internasional (Supriharjo, 2016). Kabupaten Gresik dengan situs heritage yang meliputi masjid dan makam memiliki potensi sebagai kawasan heritage UNESCO telah memenuhi kriteria sebagai peninggalan sejarah perkembangan agama Islam di Indonesia yang ditandai keberadaan makam Siti Fatimah binti Maimun (Supriharjo, 2013).

Selain peninggalan sejarah berupa cagar budaya, Kabupaten Gresik juga memiliki berbagai budaya dan kebiasaan masyarakat yang menjadi kekhasan dan identitas lokal setempat yang sangat erat kaitannya dengan budaya Islam yang berkembang di Kabupaten Gresik. Salah satu yang menarik dari berbagai tradisi ini selain karena hubungan yang erat dengan tradisi atau budaya dan hari besar dalam kepercayaan agama Islam, namun juga budaya yang berkembang di Kabupaten Gresik ini dipelopori dan dijalankan oleh masyarakat Kabupaten Gresik sendiri sebagai pelaku utama. Masyarakat dalam hal ini memegang peran tokoh utama dalam pelestarian budaya Kabupaten Gresik (Gresik, n.d.).

Pada kondisi eksisting, Kabupaten Gresik sebagai rancangan kota pusaka ini tidak didukung dengan pelestarian Peninggalan sejarah yang ada, dan terlihat pada gap yang cukup besar antara pemanfaatan dan pemeliharaan di lapangan dengan potensi yang ada (Supriharjo, 2013). Pengembangan kebudayaan berupa festival seni, budaya dan pelestarian warisan budaya menjadi program prioritas dengan kondisi awal saat ini masih belum ada cagar budaya yang dapat memenuhi capaian program pengembangan. Terdapat beberapa kendala dan masalah dalam menghadapi pengelolaan kekayaan budaya dan nilai budaya diantaranya; kurangnya perawatan dan pengelolaan situs heritage, pengadaan infrastruktur yang terbatas dalam pengembangan situs menjadi objek wisata (Supriharjo, 2013). Pada pengembangan budaya di Kabupaten Gresik juga mengalami kemunduran karena adanya perubahan dan pergeseran dalam pengadaan event budaya dari tradisi yang seharusnya. Pergeseran ketentuan dalam pengadaan event ini sedikit demi sedikit juga berpengaruh terhadap tujuan utama dan manfaat awal dari adanya event budaya tersebut. Kemudian, kurangnya pengembangan dan pemaksimalan potensi pariwisata yang cukup beragam di Kota Gresik terlihat dari kondisi eksisting yang masih kurang terawat dan terpublikasikan yang ditandai dengan kualitas bangunan yang rendah dan tidak terawat serta belum adanya regulasi yang tegas dan mengikat untuk pengelolaan kawasan. Adanya dukungan dari komunitas setempat yaitu Masyarakat Pecinta Sejarah dan Budaya (Mata Seger) yang dalam hal ini berperan mewakili masyarakat idealnya dapat menjadi sarana dan bentuk kerja sama yang baik dengan pemerintah dalam pelestarian budaya Kabupaten Gresik. Pelestarian lingkungan fisik dengan pengembangan secara keseluruhan kawasan dan bukan terpusat pada konteks Benda Cagar Budaya (BCB) untuk mendukung Kabupaten Gresik sebagai kota pusaka didukung dengan adanya konsep Historic Urban Landscape (HUL) yang merupakan pendekatan pelestarian heritage kota yang melihat pada konteks kawasan, memiliki fokus utama pada seluruh lingkungan manusia dengan semua kualitas tangible dan intangible di dalamnya (UNESCO, 2011). Pendekatan ini bertujuan untuk meningkatkan keberlanjutan perencanaan dan intervensi desain dengan memperhatikan lingkungan terbangun yang ada, intangible heritage, keanekaragaman budaya, faktor social dan ekonomi, serta lingkungan dengan nilai masyarakat lokal dan menjembatani keterlibatan komunitas, masyarakat dan swasta serta dukungan pemerintah dalam usaha konservasi dan pengembangan Gresik sebagai Kota Pusaka (UNESCO World Heritage Centre, 2008). Selain itu, sebagai sebuah definisi, memperluas pemahaman tentang kawasan heritage, mengidentifikasi elemen-elemen yang membuat keragaman kota dan menciptakan rasa tempat serta identitas kota (UNESCO, 2013). Lapisan-lapisan ini merupakan kekayaan yang perlu diakui dan 
ditingkatkan dalam strategi konservasi dan pembangunan kota. Pemahaman keberagaman budaya dan identitas dalam suatu kota akan memberikan pandangan dan pengetahuan yang baru dalam proses manajemen dan pembuatan keputusan dalam perencanaan perkembangan Kabupaten Gresik sebagai dasar untuk rencana pengembangan kawasan.

\section{METODE PENELITIAN}

Penelitian yang dilakukan ini merupakan penelitian kualitatif dengan pendekatan yang

Tabel 1. Sumber Pustaka

\begin{tabular}{cllll}
\hline No & Jenis Literatur & \multicolumn{1}{c}{ Judul } & \multicolumn{1}{c}{ Penulis } & \multicolumn{1}{c}{ Penerbit } \\
\hline 1 & Buku Sejarah & Gresik dalam Lintasan Lima Zaman & Mustakim & Pustaka Eureka \\
\hline 2 & Buku Sejarah & Satu Kota Tiga Zaman & Mustakim & Pustaka Media Guru \\
\hline 3 & Penelitian & $\begin{array}{l}\text { Babad Gresik: Suntingan Teks dan } \\
\text { Tinjauan Unsur Sastra Sejarah }\end{array}$ & $\begin{array}{l}\text { Retno Asih, Dwi } \\
\text { Handayani }\end{array}$ & $\begin{array}{l}\text { Lembaga Penelitian } \\
\text { Universitas Airlangga }\end{array}$ \\
\hline 4 & Buku Sejarah & Jelajah Gresik Kota Tua & Oemar Zainoeddin dkk. & Andhum Berkat \\
\hline 5 & Buku Sejarah & $\begin{array}{l}\text { Gresik sejarah Bandar Dagang dan Jejak } \\
\text { Awal Islam Tinjauan Historis Abad XIII } \\
- \text { XVII }\end{array}$ & Mustakim & Citraunggul Lasana \\
\hline 6 & Buku Sejarah & Grissee Tempoe Doeloe & $\begin{array}{l}\text { Dukut Imam Widodo } \\
\text { dkk. }\end{array}$ & $\begin{array}{l}\text { Pemerintah Kabupaten } \\
\text { Gresik }\end{array}$ \\
\hline 7 & Penelitian & Babad Gresik & $\begin{array}{l}\text { Aminuddin Kasdi, } \\
\text { Sumarno }\end{array}$ & LPPM UNESA \\
\hline 8 & Penelitian & Perkembangan Kota Gresik & Aminuddin Kasdi & UNESA University Press \\
\hline 9 & Penelitian & Kepurbakalaan Sunan Giri & Aminuddin Kasdi & UNESA University Press \\
\hline 10 & Buku Sejarah & Memahami Sejarah & Aminuddin Kasdi dkk. & UNESA University Press \\
\hline
\end{tabular}

\begin{tabular}{ccl}
\hline Stakeholder & Nama Narasumber & \multicolumn{1}{c}{ Peran Narasumber } \\
\hline Expert & Dr. Masyhudi, M.Ag & $\begin{array}{l}\text { - Dosen Fakultas Adab dan Humaniora UINSA } \\
\text { • Penulis Buku Sejarah }\end{array}$ \\
\hline \multirow{2}{*}{ Expert } & Prof. Dr. H. Aminuddin Kasdi, M.S & $\begin{array}{l}\text { - Dosen Fakultas Pendidikan Sejarah UNESA } \\
\text { - Penulis Buku Sejarah }\end{array}$ \\
\hline
\end{tabular}

Sumber: Hasil Analisis, 2019

kota. Stadia perkembangan kota akan menggambarkan identitas dan meletakkan Kabupaten Gresik khususnya kawasan kota lama di depan dan di tengah perencanaan yang berkelanjutan dengan mempertahankan identitas kawasan yang ditandai dengan bangunan dan benda peninggalan sejarah serta lingkungan terbangun yang ada, intangible heritage, keanekaragaman budaya, faktor social dan ekonomi, serta memperhatikan lingkungan kebersamaan dengan nilai masyarakat lokal (Jokiletho, 2008).

Melihat besarnya potensi sejarah dan peninggalan sejarah yang dimiliki Kabupaten Gresik juga rencana pengembangan Gresik Kota Pusaka. Namun, kondisi eksisting yang kurang membuat gap dengan potensi yang ada. Untuk itu dilakukan penyusunan stadia digunakan yaitu rasionalistik (Rahmawati et al., 2016). Untuk menyusun stadia perkembangan Kabupaten Gresik dilakukan studi pustaka dengan beberapa sumber literatur, yang terdiri atas buku sejarah, dan penelitian sebelumnya (Tabel 1)

A. Teknik Pengumpulan Data

Data yang digunakan dalam penelitian ini didapat dengan melakukan studi pustaka dan in depth interview kepada expert terpilih melalui purposive sampling.

Wawancara dilakukan pada expert yang memiliki pengetahuan. mengenai perkembangan Kabupaten atau peristiwa sejarah di Gresik, sehingga proses penyusunan stadia perkembangan Kabupaten Gresik menjadi sesuai. 
Analisis stakeholder untuk pemerintah dimulai dengan meninjau tugas pokok dan

identifikasi terhadap pengaruh expert dalam pengembangan artefak.

Selanjutnya, diberikan kriteria pemilihan narasumber expert dengan teknik purposive sampling. Melalui teknik purposive sampling diharapkan dapat memunculkan sampel penelitian yang representatif dalam penelitian ini, sehingga sesuai tujuan yang diharapkan yaitu mendapatkan responden yang tepat.

Definisi Operasional:

- Artefak: benda yang dapat dipindahkan apa fungsi dari dinas terkait, sedangkan pada stakeholders dari masyarakat dipilih dengan

B. Variabel Penelitian

Variabel yang digunakan dalam penelitian ini untuk menentukan tahapan peerkembangan Kabupaten Gresik dan peninggalan sejarah Kabupaten Gresik dapat dilihat pada Tabel 2 .

analisis konten dipilih untuk menyusun kesimpulan dengan berdasarkan hasil in depth

Tabel 2. Variabel

\begin{tabular}{cl}
\hline Indikator & \multicolumn{1}{c}{ Variabel } \\
\hline Waktu & Periode \\
\cline { 2 - 2 } Lingkungan & Sama \\
\cline { 2 - 2 } & Bentuk Pemerintahan \\
\cline { 2 - 2 } & Pdministratif \\
\cline { 2 - 2 } & Pusat Kota \\
\hline \multirow{2}{*}{ Masyari Kota } \\
\hline \multirow{2}{*}{$\begin{array}{c}\text { Peninggalan } \\
\text { Sejarah }\end{array}$} & Karakteristik \\
\cline { 2 - 2 } & Mata Pencaharian \\
\cline { 2 - 2 } & Fitur \\
\hline
\end{tabular}

Sumber: Hasil analisis, 2019

pun yang dibuat atau dimodifikasi oleh manusia setidaknya berusia 50 tahun

- Fitur: benda yang tidak dapat diangkut atau dipindahkan yang dibuat, dimodifikasi manusia setidaknya berusia 50 tahun

- Situs: lokasi temuan arkeologis

- Nilai sejarah: merupakan silsilah, riwayat, asal-usul setiap stadia atau periode waktu

- Nilai budaya: merupakan warisan cara hidup masyarakat yang dapat berkembang, dimiliki bersama sebuah kelompok, dan diwariskan pada tiap stadia

C. Teknik Analisis Data

Pengolahan data yang digunakan pada penilitian ini menggunakan teknik Content Analysis (CA) atau analisis konten. Teknik interview yang berisi pendapat expert terkait kerangka stadia perkembangan Kabupaten Gresik berdasarkan studi pustaka. Proses diawali dengan menyusun kerangka stadia perkembangan Kabupaten Gresik dengan studi literature yang dilanjutkan dengan triangulasi melalui in depth interview dengan expert. Kemudian dilakukan analisis untuk menentukan stadia perkembangan utama Kabupaten Gresik

\section{HASIL DAN PEMBAHASAN}

Kabupaten Gresik memiliki luas wilayah administratif mencapai 1.322,327 $\mathrm{km}^{2}$, merupakan salah satu penyangga utama Kota Surabaya. Kabupaten Gresik terbagi dalam 18 kecamatan yang terdiri atas 330 desa dan 26 kelurahan. Sebagian wilayah Kabupaten 
Gresik merupakan daerah pesisir pantai, yaitu memanjang mulai dari Kecamatan Panceng, Ujungpangkah, Sidayu, Bungah, Manyar, Kebomas, dan Gresik serta Kecamatan Tambak dan Sangkapura yang lokasinya berada di Pulau Bawean. Batas wilayah
Kabupaten Gresik secara administratif dibatasi oleh (Gambar 1):

- Utara: Laut Jawa

- Timur: Selat Madura dan Kota Surabaya

- Selatan: Kabupaten Sidoarjo dan Mojokerto

- Barat: Kabupaten Lamongan

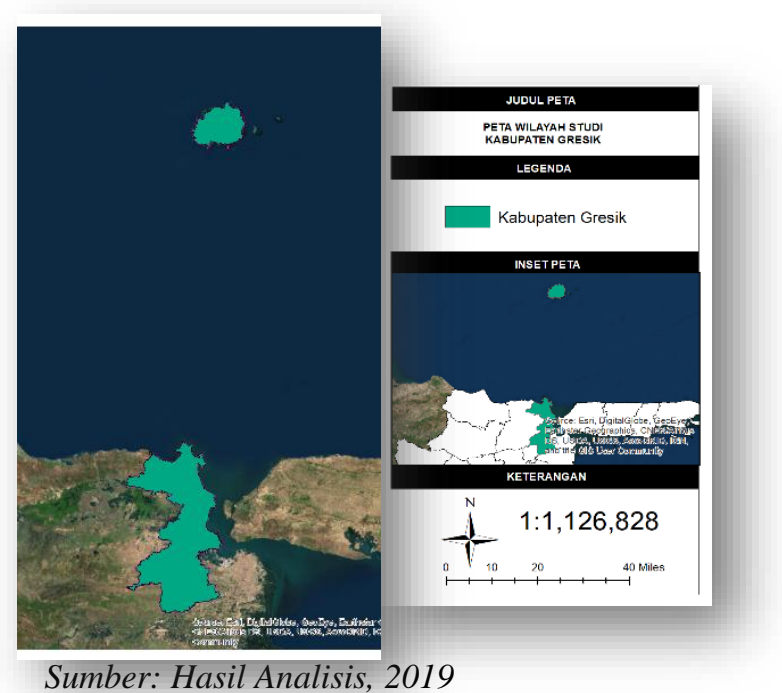

\section{Gambar 1. Peta Wilayah Studi}

Proses penyusunan stadia perkembangan Kabupaten Gresik dimulai dengan membuat kerangka stadia perkembangan dengan studi literatur. Berdasarkan informasi yang dikumpulkan dan analisis dari sumber literature berupa penelitian dan buku sejarah. Perkembangan Kabupaten Gresik dibagi menjadi 5 periode waktu yang secara lebih detail dijelaskan sebagai berikut (Gambar 2).

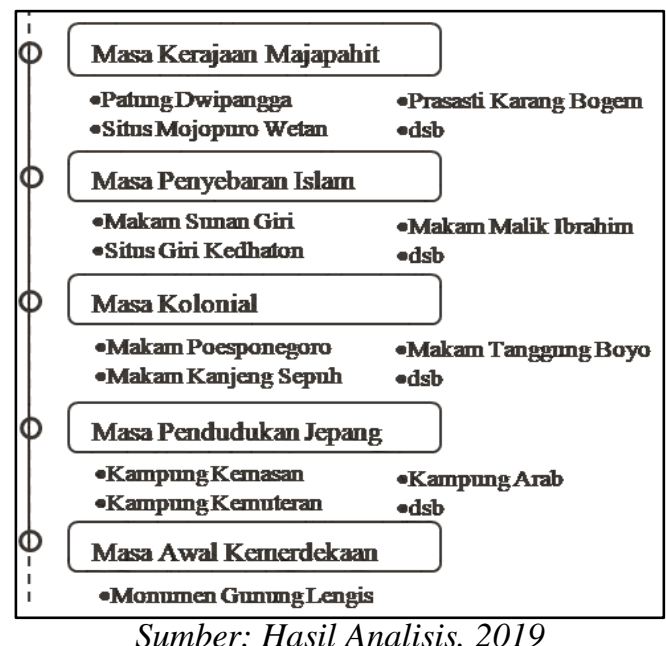

Gambar 2. Tahapan Perkembangan Gresik

1. Masa Kerajaan Majapahit

- Nama

Sampai saat ini belum dipastikan sejak kapan mulainya pengaruh kerajaan
Hindu-Budha ini di kawasan Gresik, namun munculnya Gresik dalam sejarah Kerajaan Majapahit dan memiliki arti penting bagi kerajaan ini sampai akhir 
abad ke-15 M cukup menjadi bukti bahwa Gresik merupakan bagian dari Kerajaan Majapahit. Selain itu juga terdapat teks Arab yang menyebut Gresik sebagai Qarr-syaik (Mustakim, 2005)

\section{- Ciri Kota}

Berbagai situs dan peninggalan sejarah menunjukkan bahwa pada masa kerajaan yang bercorak Hindu-Buddha, keberadaan Gresik sudah tampak, dan dapat dikatakan dimulai sejak abad ke-10 M, bertepatan pada masa kerajaan Kediri (1045-1221 M). Pada masa Raja Airlangga hingga Kerajaan Majapahit pantai utara Jawa Timur memiliki peranan penting pada jalur perekonomian, salah satunya dengan menjadikan Tuban sebagai pelabuhan internasional yang dikenal dengan nama Kambang Putih. Desa Roomo mempunyai ciri-ciri khas sebagai Kota pelabuhan yakni masyarakatnya hidup secara terbuka dan penduduk sebagian besar berprofesi sebagai nelayan (Zainoeddin \& dkk, 2013).

- Pusat Kota

Kecamatan Bungah merupakan salah satu pemukiman kuno dan daerah penting di Gresik, salah satu penyebabnya berdasarkan fakta bahwa di daerah tersebut pada masa lalu terdapat pelabuhan kuno yang ada di Mengare Bungah Gresik.

- Artefak

Salah satu temuan sebuah prasasti di sebuah dinding goa di Desa Gosari, Ujungpangkah, Gresik menjadi salah satu bukti bahwa pada masa kerajaan Majapahit, Gresik merupakan bagian dari kekuasaan kerajaan tersebut. Prasasti beraksara Jawa kuno ini ditulis pada tahun 1298 Saka atau tahun 1376. Prasasti tersebut ditulis oleh salah satu murid San Rama Samadaya pada jaman keemasan atau kejayaan Majapahit yang saat itu rajanya adalah Hayam Wuruk Seri Radjasanagara tahun 1272 Saka atau 1359 Masehi sampai 1311 Saka atau 1389 Masehi. Selain itu, terdapat pula Prasati Biluluk (1366-1397 M) di Biluluk Lamongan. (Gresik, n.d.)
Selain peninggalan dari Majapahit, terdapat pula temuan benda-benda dari Dinasti Yuan (1271-1368 M), berupa keramik yang ditemukan di situs Gosari Gresik. Berita Cina (Ma Huan dalam bukunya Ying-yai Sheng-lan) dari Dinasti Ming (1368 1644 M). Selain informasi yang didapat dari Babad Gresik, keberadaan Desa Roomo sebagai pemukiman kuno di zaman kerajaan Majapahit juga diperkuat dengan temuan benda-benda arkeologis yang ditemukan Tim Peneliti dan Penyusun Sejarah Hari Jadi Kota Gresik. Mereka menemukan bekas-bekas fondasi masjid kuno, yang menurut cerita tradisional masjid tersebut belum sempat terwujud. Selain itu di sekitar Desa Roomo juga telah ditemukan sumur-sumur kuno dan beberapa batu umpak.

Temuan yang keduanya ditemukan di wilayah Bungah Gresik. Peninggalan itu berupa prasasti Karang Bogem yang berangka tahun $1387 \mathrm{M}$ berisi penjelasan tentang system pembayaran hutang nelayan kepada kerajaan dengan hacan (terasi) demikian pula dengan hutang penyadap nira. Disamping itu ada pula Patung atau arca Drawapala, ditemukan di sebuah dusun yang terletak sekitar 8 $\mathrm{km}$ dari pusat kota Bungah bernama Mojopurowetan yang merupakan bentuk penjaga pintu gerbang suatu bangunan suci yang diperkirakan dahulu terdapat di lokasi tersebut. Selain itu, Hasil ekskavasi yang dilakukan Suhartanto dari Suaka Peninggalan Sejarah dan Purbakala Jawa Timur pada tahun 1989, menunjukkan bahwa di sekitar situs juga telah temukan struktur batu putih, temuan fragmentaris gerabah masa kerajaan Majapahit, dan pecahan keramik asing masa Dinasti Sung dan Yuan.

- Masyarakat

Para pedagang asing saat itu kebanyakan berasal dari Gujarat, Calicut, Banggala, Siam, Cina, dan Liu-Kiu (Lequeos). Terdapat teori yang mengatakan pada abad ke-11 M Gresik sebagai kota pelabuhan sudah dikenal oleh pedagang asing. Terutama pedagang yang 
beragama Islam. Informasi dalam Babad Gresik itu cukup menjadi bukti bahwa pada masa kerajaan Majaphit di Gresik sudah ada penguasa pelabuhan yang biasa disebut syahbandar. Secara politis syahbandar adalah sebagai penguasa wilayah pelabuhan dan segala aktivitasnya, yang diangkat oleh raja Majapahit sebagai penguasa saat itu. Adapun salah seorang syahbandar yang pertama di Gresik adalam Maulana Malik Ibrahim, dilanjutkan Ratu Pendito (Raden Santri) sekitar tahun 1419 M dengan gelar Ratu Pandita dan Nyai Ageng Pinatih tahun 1458-1477 M di sekitar Bungah.

Kemungkinan besar Desa Roomo dahulunya adalah sebuah komunitas sosial yang mempunyai karakteristik sebagai kota dagang, sebagai tempat bertemunya para pedagang dari berbagai jurusan, baik dari luar negeri maupun dalam negeri dengan berbagai macam komoditi perdagangannya.

- Lingkungan

Keberadaan Gresik yang terletak antara Tuban dan pusat kota Majapahit, sangat mungkin bahwa wilayah itu juga ikut dan kota- kota pelabuhannva di sepanjang pantai utara Pulau Jawa sekitar tahun $1512 \mathrm{M}$ menjadi pusat perdagangan yang besar dan terbaik di seluruh Jawa, sehingga mendapat julukan "Permata dari Jawa".

Berdasarkan data arkeologis, maka dapat dikatakan bahwa islamisasi yang pertama dilakukan di Gresik, bahkan di Jawa Timur adalah di Desa Leran Manyar Gresik. Salah satu buktinya adalah ditemukannya sebuah batu nisan bertulis di atas makam seorang perempuan bernama Siti Fatimah Binti Maimun yang berangka tahun $1082 \mathrm{M}$ (Gambar 3). Selain itu keberadaan pemukiman kuno di Leran Manyar Gresik juga diperkuat dengan sebuah temuan berupa sebuah prasati perunggu yang kemudian disebut Prasasti Leran. Prasasti yang ditulis dengan bahasa Jawa Kuno ini diperkirakan berasal dari abad ke-12 M, yang menyebutkan secara jelas sebuah daerah perdikan bernama Sima ri-Leran, dan yang memiliki bangunan tempat suci agama Hindu, "Rahyangta Kutik". Berita tersebut menjelaskan bahwa pada saat itu status desa Leran adalah sebuah desa

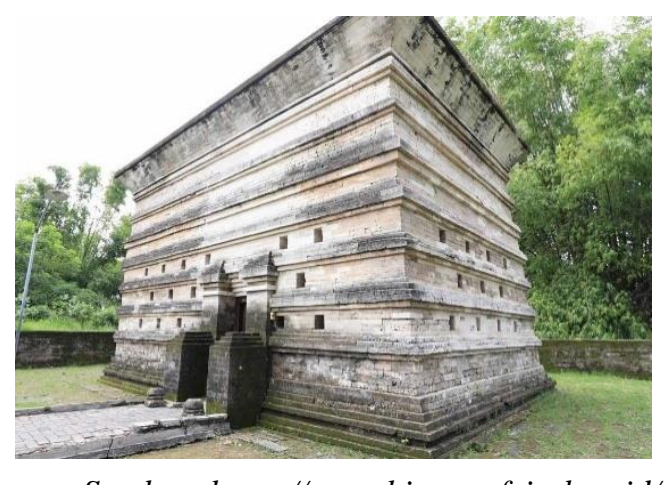

Sumber: https://www.historyofcirebon.id/

\section{Gambar 3. Makam Fatimah binti Maimun}

bersentuhan dengan jaringan tersebut, sebab jalur transportasi saat itu yang digunakan dari Tuban - Sedayu - Gresik - Surabaya - Majapahit.

Pada abad ke-14 M Jawa mempunyai empat kota tanpa tembok, yang termasuk Gresik. Tome Pires telah melaporkan, bahwa keadaan kota pelabuhan Gresik perdikan atau sima, yang di dalamnya hidup orang-orang bebas dan identik dengan perdagangan. 
Selain di Leran Manyar Gresik, di tempat lain yang masih dalam wilayah kecamatan yang sama juga ditemukan sebuah perkampungan kuno. Tepatnya di Desa Roomo Manyar Gresik, tepatnya 4 kilometer di sebelah timur Desa Leran. Dalam beberapa cerita lisan disebutkan, bahwa desa tersebut merupakan perkampungan kuno yang keberadaannya cukup strategis sebagai kota perdagangan pada masanya. Sumber tradisional berupa Babad Hing Gresik yang menyebutkan Maulana Malik Ibrahim dan Keluarganya serta perannya di daerah tersebut bahkan pantai yang pertama oleh orang Gresik wetan diberi nama sebagai desa Rama hingga kini. Sebab orang Jawa menyamakan sebutan bapak dengan rama, tempat berdiam bapaknya. (Mustakim, 2017)

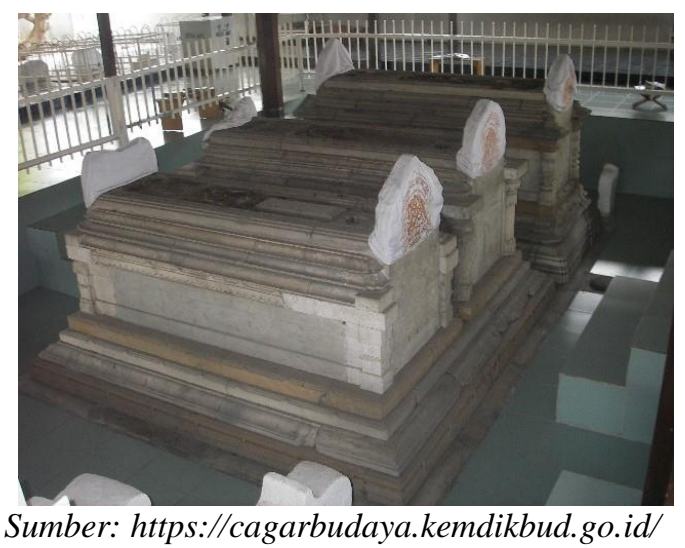

\section{Gambar 4. Makam Maulana Malik Ibrahim/Sunan Gresik}

Maulana Malik Ibrahim sebagai tokoh sejarah dapat dibuktikan dengan keberadaan makamnya di Kampung Gapuro-Gresik (sekarang). Pada jirat makamnya diperoleh informasi bahwa beliau meninggal pada tanggal 12 Rabiul Awal 822 H/1419 M (Gambar 4).

Kerajaan majapahit akhirnya mengalami keruntuhan pada akhir abad ke XV M. Menjelang runtuhnya Kerajaan Majapahit, daerah-daerah kekuasaan kerajaan ini banyak yang melepaskan diri karena lemahnya kontrol dari pemerintah pusat. Banyaknya daerah yang melepaskan diri berdampak pula pada menurunnya pendapatan ekonomi Kerajaan Majapahit. Seiring dengan merosotnya Kerajan Majapahit proses islamisasi di wilayah pesisir semakin kuat diperankan oleh para ulama pedagang, diantaranya dikenal sebagai Wali Songo. (Gandis Prameswari et al., 2013)

Tabel 3. Benda Arkeologi Masa Kerajaan Majapahit

\begin{tabular}{lcl}
\hline \multicolumn{1}{c}{ Benda Arkeologi } & Tahun & \multicolumn{1}{c}{ Keterangan } \\
\hline $\begin{array}{l}\text { Makam Siti Fatimah binti } \\
\text { Maimun }\end{array}$ & $1082 \mathrm{M}$ & \\
\hline Prasasti Karang Bogem & $1387 \mathrm{M}$ & Berasal dari Zaman Majapahit \\
\hline Prasasti Biluluk & $1366-1397 \mathrm{M}$ & $\begin{array}{l}\text { Hayam Wuruk }(1350-1389 \mathrm{M}) \\
\text { Wikramawardhana }(1389-1429 \mathrm{M})\end{array}$ \\
\hline
\end{tabular}




\begin{tabular}{lc}
\hline Arca Dwarapala & Sudah rusak sejak 1902 \\
\hline $\begin{array}{l}\text { Makam Maulana Malik } \\
\text { Ibrahim }\end{array}$ & $1419 \mathrm{M}$ \\
\hline Sumber: Hasil Analisis 2019 &
\end{tabular}

2. Masa Penyebaran Islam di Nusantara

- Nama

Pada periode ini, penguasa Giri Gresik bergelar Sunan kemudian panembahan, satu gelar lebih rendah disbanding sunan. Kabarnya perubahan gelar ini atas perintah Sultan Pajang. (Kasdi \& Sumarno, 2016)

- Ciri Kota

Kota-kota pelabuhan di Jawa, seperti Gresik mempunyai hubungan yang intensif dengan pusat-pusat perdagangan seperti Malaka, Samudera Pasai, Gujarat, dan Persia. Semua wilayah itu merupakan pusat agama Islam dalam abad 15 M.(Mashuri, 2017)

Berbagai sumber agama mengabarkan bahwa sejak periode Sunan Giri I Islam menyebar dari Gresik ke Maluku, Madura, dan sepanjang pantai utara Jawa. Sunan Giri II melanjutkan Islamisasi pulau Madura, dan membantu Maluku melawan Portugis. Di bidang ekonomi, Sunan Giri II membantu menampilkan Gresik sebagai pelabuhan terbesar di Jawa menyusul jatuhnya Malaka oleh Portugis tahun 1511 M. Berbeda dengan Sunan Giri II, catatan sejarah kegiatan Sunan Giri III dalam berbagai sumber tidak dapat ditemukan. Ia hanya memerintah selama tiga tahun, kemudian diganti oleh Sunan Giri IV. Pada masa Sunan Giri IV, pemerintah kerajaan Giri Gresik mencapai zaman keemasan. Di bidang agama dan politik ia memperkokoh ukhuwah Islamiyah dengan Maluku, membantu Maluku dalam menyerang Portugis pada tahun 1565 M. Melalui ekspedisi militer, ia menaklukkan dan menglslamkan Kediri pada tahun $1579 \mathrm{M}$, menglslamkan Pasuruan pada tahun 1596 M. Seiring dengan penetrasi Belanda, terjadi satu titik balik. Dimana Sunan Giri IV berhubungan baik dengan Portugis untuk menghadapi Belanda. Di tengah kerajaan-kerajaan di Nusantara, peran politik Sunan Giri IV sangat menonjol, misalnya menobatkan Adiwijaya sebagai
Sultan Pajang (1581 M), memberikan legitimasi atas tampilnya Mataram menyusul redupnya Pajang, serta menampilkan diri sebagai penengah dalam pertentangan antara Mataram dengan Surabaya. Raja-raja lain ketika berbicara kepadanya selalu dengan tangan terlipat. Penguasa Belanda J.P. Coen menyebutnya sebagai Paus Islam. Di bidang ekonomi Sunan Giri IV membawa Giri Gresik zaman keemasan. Kerajaan meredup pada akhir Kekuasaannya, menyusul penetrasi VOC tahun 1602 M dengan monopoli perdagangannya. (Kasdi \& Sumarno, 2016)(Hilmiyyah, 2019)(Widodo \& dkk, 2004)

- Pusat Kota

Dalam Babad Hing Gresik diberitakan, bahwa sepuluh tahun setelah meninggalnya Nyai Ageng Pinatih dan disintegrasi Majapahit, Raden Paku mendirikan Kerajaan Giri Gresik yang berpusat di Giri Kedaton. Berdasarkan cerita, Raden Paku yang pertama menggagas dan membangun tempat ini pada 1487. Pria yang kemudian bergelar Sunan Giri itu memilih sebuah bukit untuk tinggal. Konon, putra Maulana Ishak ini memilih bukit itu karena tanahnya mirip dengan tempat tinggal ayahnya di Pasai. Raden Paku diangkat dalam rapat para sunan sebagai raja kerajaan Islam pertama di Tanah Jawa pada tahun $1487 \mathrm{M}$, mendahului berdirinya kerajaan Demak. Dari beberapa sumber dapat diketahui bahwa penguasa Giri Gresik secara berturutturut antara lain Raden Paku atau Sunan Giri I (1487-1506 M), Sunan Dalem atau Sunan Giri II (1506-1545 M), Sunan Sedamargi atau Sunan Giri III (15451548 M), dan Sunan Prapen atau Sunan Giri IV (1548-1605 M). Masa ini disebut sebagai masa kesunanan, karena sesudah Sunan Giri IV penguasa Gresik tidak lagi bergelar sunan tapi panembahan. (Kasdi, 2017)

- Masyarakat 
Pentingnya bandar dagang Gresik bagi ditandai dengan pengangkatan syahbandar (kepala pelabuhan) oleh Raja Majapahit. Cukup menarik, ulama pedagang selalu menempati posisi utama dalam jabatan ini. Syahbandar sekaligus ulama inilah yang menjadi pendukung dan pendorong awal perkembangan
Islam di Gresik, diantaranya Maulana Malik Ibrahim (1378-1419 M), Raden Ali Hutomo atau Raja Pandita (1419$1458 \mathrm{M}$ ), dan Nyai Ageng Pinatih (14581577 M) (Gambar 5).

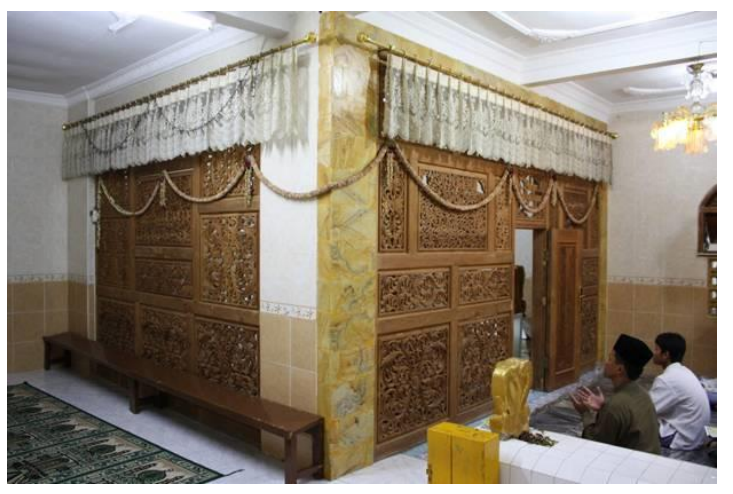

Sumber: https://islamindonesia.id/

\section{Gambar 5. Makam Nyai Ageng Pinatih}

- Lingkungan dan Artefak

Penyebaran Islam dimulai karena adanya hubungan dengan negara - negara Islam. Hubungan antara Timur Tengah dengan Asia Tenggara sudah lama terjalin sebelum Islam masuk pada awal abad ke7 M. Hubungan itu dalam bentuk per dagangan yang ramai antara keduanya melalui pelayaran laut. (Tim Peneliti dan Penyusun Sejarah Sunan Drajat, 1998:9). Gresik sebagai bandar dagang selalu mengalami perubahan. Pada awal abad ke-15 terdapat dua bandar dagang yaitu
Bandar Dagang Jaratan dan Bandar Dagang Gresik.

Dua pelabuhan kembar ini terletak berhadapan di muara sungai. Diperkirakan bahwa Pelabuhan Gresik pada masa itu terletak di Desa Karang Kiring sekarang yang berhadapan dengan Sungai Lamong, sedangkan Pelabuhan Jaratan terletak di Desa Mengare, berhadapan dengan Sungai Bengawan Solo Lawas.

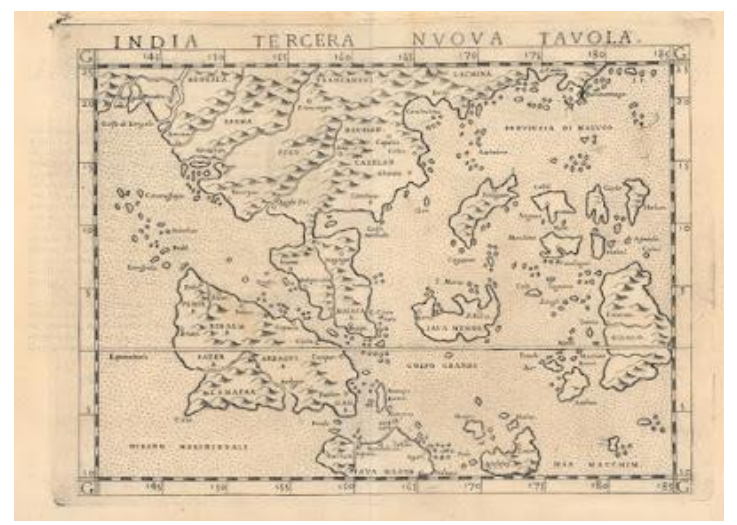

Sumber: http://ekojarwantosmadah.blogspot.com/

Gambar 6. Gresik (Agati) tahun 1561 buah karya petualangan (pedagang) bangsa Eropa (Portugis) 


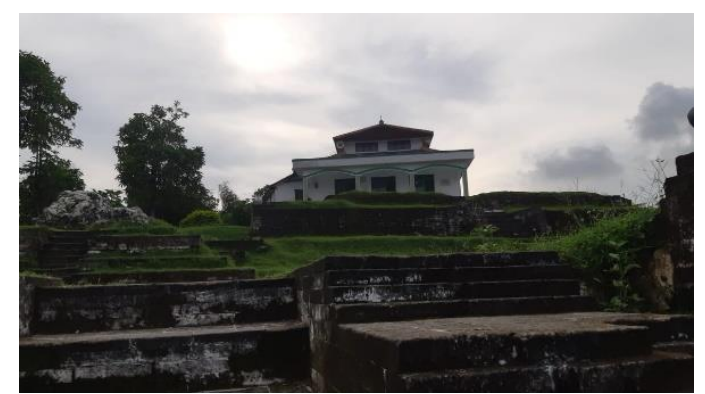

Sumber: Dokumentasi Penulis, 2019

Gambar 7. Situs Giri Kedhaton

Simpul kedatangan Islam di Bawean yakni di Diponggo. Disana terdapat makam Dewi Wardah (Gambar 8), yang menurut penuturan lisan penduduk setempat, yang dimakamkan di situ adalah istri Sunan Giri.Di Bawean banyak dijumpai atap bergaya Minangkabau banyak dikunjungi peziarah.

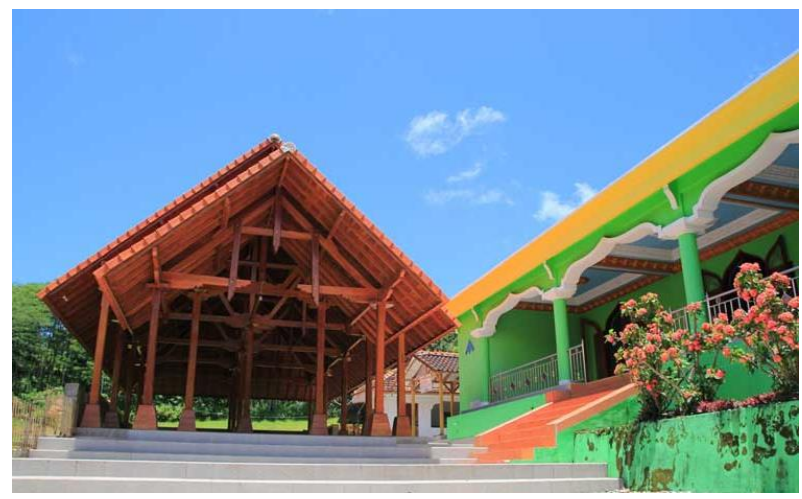

Sumber: http://disparbud.gresikkab.go.id/

Gambar 8. Makam Dewi Wardah

Diperkirakan Islam masuk Bawean pada abad ke-15. Dewi Wardah adalah putri Kiai Ageng Bungkul, pembesar Soerabaia keturunan dari Majapahit. Sebelumnya Sunan Giri dinikahkan dengan Dewi Murtosiyah, putri Sunan Ampel. Lantas, Sunan Giri menikah lagi dengan Dewi Wardah. Dalam waktu sehari itu menikah dua kali, Mula-mula ia dinikahkan dengan putri Sunan Ampel, Dewi Murtosiyah yang memang sudah lama akan dijodohkan, kemudian dinikahkan dengan putri Kiai Ageng
Bungkul, Dewi Wardah. Tetapi Dewi Wardah kemudian rupanya tidak mau dimadu, dan pergi meninggalkan Grissee. la berlayar menuju Bawean,

akhirnya menetap dan wafat di sana, dimakamkan di Diponggo.

Proses Islamisasi sebagai gerakan sosial agama dipermudah oleh beberapa faktor, antara lain: (1) Suasana keterbukaan antar individu di kota-kota pantai memungkinkan untuk menerima pengaruh baru yang dianggap lebih baik 
dan mulia, diantaranya berpindah agama (2) Bersamaan itu terjadi disintegrasi masyarakat dengan nilai lama sehingga diperlukan identitas baru dengan nilai baru. (3) Merosotnya kekuasaan Majapahit yang berideologi Hindu berakibat pada perubahan struktur kekuasaan. Dalam hal ini agama Islam berperan sebagai tiang pendukungnya. Dalam proses perubahan sosial seperti tersebut para wali memegang kepemimpinan yang sifatnya kharismatik.

Pasca kesunanan, penguasa Giri Gresik bergelar panembahan, satu gelar lebih rendah disbanding sunan. Kabarnya perubahan gelar ini atas perintah Sultan Pajang. Berturut-turut penguasa Giri Gresik pasca kesunanan adalah Panembahan Kawisguwa (1605-1616 M), Panembahan Agung (1616-1638 M), Panembahan Mas Witono (1638-1660 M). Pada masa Panembahan Kawisguwa, Giri Gresik mulai diincar oleh Mataram yang menjalankan politik ekspansinya melalui tangan Pangeran Surabaya, sebelum akhirnya secara penuh Giri Gresik dikuasai oleh VOC pada masa Panembahan Mas Witono.(Mustakim, 2005)

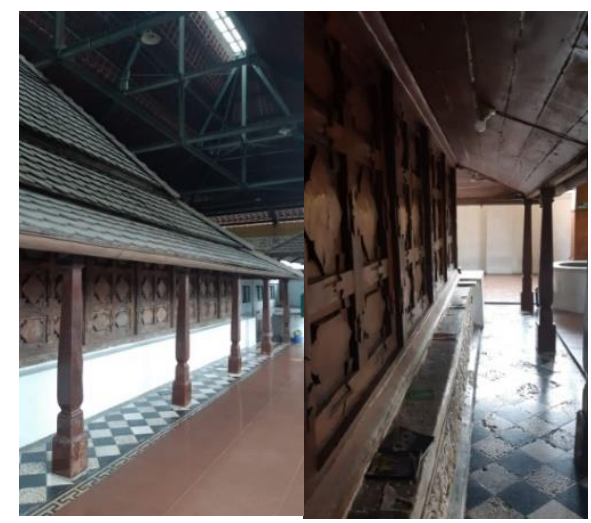

Sumber: Dokumentasi Penulis 2019

Gambar 9. Dinding dan Cungkup Makam Sunan Giri

Tabel 5. Benda Arkeologi Masa Penyebaran Islam

\begin{tabular}{lcl}
\hline \multicolumn{1}{c}{ Benda Arkeologi } & Tahun & Keterangan \\
\hline Giri Kedhaton & 1486 & \\
\hline Makam Sunan Giri & 1506 \\
\hline Makam Sunan Prapen & 1605 & \\
\hline Makam Raden Santri & 1449 & \\
\hline Makam Nyai Ageng Pinatih & 1483 & \\
\hline Makam Siti Zainab (Dewi Wardah) & - & Tahun pembangunan (-), diketahui makam \\
\hline Makam Putri Campa (Cempo) & - & sama di Trowulan \\
\hline Sumber: Hasil Analisis 2019 & &
\end{tabular}

Dibidang tulisan dan bahasa Arab nampak sekali pada nisan-nisan di makam orang islam, bahkan gaya tulisannya sudah mengandung gaya yang tinggi, seperti gaya kufi, sebagaimana yang terpahat pada batu nisan Siti fatimah binti Maimun di Gresik, berangka $475 \mathrm{H}$ atau $1082 \mathrm{M}$ Setelah penggunaan tulisan dan huruf Arab meluas, maka menggeser tulisan 
Sansekerta yang sebelumnya mendominasi huruf di Nusantara.

Bahasa Melayu kemudian ditulis dengan huruf Arab, yang dikenal dengan tulisan Jawa Pegon atau tulisan Jawi. Pengaruh seni suara terbukti dengan adanya lagu-lagu berirama padang pasir,

3. Masa Kolonial

- Nama

Sidayu-Gresik dalam Bayang-bayang Mataram dan VOC (1626-1717 M) Sidayu pada saat ini merupakan kota kecamatan di bawah pemerintah Kabupaten Gresik. Sebelum menjadi bagian dari Kabupaten Gresik Sidayu ternyata memiliki sejarahnya sendiri. Dimana Sidayu pernah memiliki pengaruh yang sangat besar dalam percaturan politik Mataram kira-kira sejak abad ke-16 M.

- Ciri dan Pusat Kota

Meilink Roelofsz dalam bukunya tentang perdagangan di Asia dan pengaruh Eropa di kepulauan Nusantara antara tahun 1500-1630 menyebutkan bahwa diduga Sidayu telah ada sejak masa peralihan dari masa klasik ke masa Islam sebagai sebuah daerah agraris feodal, terletak diantara Tuban dan Gresik. Pantai di Sidayu tidak baik untuk berlabuh. Meskipun penguasa di beragama Islam, penduduk di sekitarnya sebagian besar adalah penganut Hindu. Ketika institusi politik di Jawa mulai menunjukkan dinamikanya menyusul redupnya Giri pasca kesunanan, Surabaya menunjukkan jati dirinya sebagai negara yang kuat dan dianggap sebagai lawan dari Mataram. Menurut Artus Gijsels (Gubernur Ambon) yang mengunjungi Surabaya pada tahun 1620, raja Surabaya selain mempunyai sekutu juga mempunyai daeralh-daerah jajahan, antara lain Gresik Jortan, dan Sidayu. Gresik misalnya menurut surat dari loji Belanda (de Nederlandsch loge), tertanggal 26 Mei 1610 waktu itu telah memiliki seorang Kanjeng Gubernur Reksa Dana, yang mungkin adalah seorang Cina.(H.J.de Graaf 1987 16-17). Sidayu mulai banyak disebutkan baru setelah Mataram dibawah pemerintahah dziba', samrah, dan hadrah. Seni arsitektur nampak pada bangunan masjid.Sedangkan seni sastra ditandai dengan karya karang mengarang dalam bahasa Melayu, Jawa, dan bahasa lokal lainnya. (Tim Peneliti dan Penyusun Sejarah Sunan Drajat, 1998: 13).

Amangkurat I (Tegal Wangi), terkait gelokal politik yang timbul. Sidayu berkali-kali diperebutkan baik oleh Kartasura, Surabaya-Bali juga Loji Gresik yang dibantu VOC. Melihat hal itu Sidayu dapat dianggap sebagai Kota penting dalam pertahanan pasukan Kartasura. Hal ini bisą dimengerti, karena Sidayu selain merupakan akses yang strategis untuk pengiriman pasukan dan logistik, juga sebagai jalur yang menghubungkan dengan kota lainnya, seperti Surabaya, Gresik dan Tuban.

Di Jawa dan Madura Pemerintahan Hindia Belanda terbagi menjadi beberapa bagian, dimana pemerintahan pusat disebut dengan Gewest atau Provincie atau Gubernuran dipimpin oleh seorang Gubernur Jenderal. Gubernur Jenderal secara urut membawahi karesidenan (residentie), Afdeeling, kabupaten (regentshcap), district (kawedanan), kecamatan (onder district), dan desa. Karesidenan Surabaya membawahi Afdeeling Gresik, sedangkan Afdeeling Gresik membawahi Regentshcap Gresik, Sidayu, dan Lamongan. (Mustakim, 2010)

- Artefak

Bidang militer dan pertahanan pada periode ini sangat diutamakan karena Nusantara dibawah ancaman Inggris. Maka apa yang dilakukan oleh Daendels adalah mempertahankan Pulau Jawa sebagai pusat keuasaannya dari ancaman Inggris. Langkah-langkah Daendels dalam bidang militer dan pertahanan adalah Membangun pabrik senjata di Gresik dan Semarang, Membangun jalan raya dari Anyer sampai Panarukan juga melewati Gresik. Membangun bentengbenteng pertahanan, Meningkatkan kesejahteraan prajurit. Secara otomatis kebijakan Daendels juga berdampak pada kuatnya eksploitasi tahan jajahan, 
akhimya pula berdampak pada kemiskinan, kebodohan, dan keterbelakangan

- Masyarakat

Pergulatan Politik Giri-Gresik versus Madura (1738 M Pada Ketika Pangeran Puspa Ita sedang berkuasa di Giri dan Bupati Nala Dika (Penggede) berkuasa di Gresik, di Jawa Timur dan Jawa Tengah berkobar perlawanan Trunojoyo terhadap Mataram. Pada pertengahan tahun 1675, Trunojoyo dari Madura, dengan bantuan orang-orang Makasar dibawah Karaeng Galesong dan orangorang Mataram dibawah Raden Kajoran telah mengangkat senjata melawan Amangkurat I, raja Mataram. Berturutturut yang diduduki adalah Pasuruan, Pajarakan, Gombong dan Gorongan. Sebagian dari pasukan orang-orang Madura. Pemerintahan Hindia Belanda di Gresik. Berbagai kemelut dalam tubuh VOC, utamanya korupsi, berdampak pada kemunduran kongsi dagang ini. Pada 1795 dibentuk panitia pembubaran VOC. Pada tahun itu pula hak-hak istimewa VOC dihapus. VOC dibubarkan pada tanggal 31 Desember 1799 dengan saldo kerugian sebesar 134,7 juta gulden.(Mustakim, 2005)

Selain itu, tumbuh berbagai organisasi nasional diantaranya; (1) Sarekat Islam yang didirikan oleh Saman Hudi di Solo tahun 1911, (2) Nahdlatul Ulama yang didirikan oleh Hasyim Asyari di Surabaya tahun 1926 kemudian mulai bergerak di Gresik oleh Kiai Sholeh murid Hasyim Asyari, (3) Muhamadiyah yang didirikan Ahmad Dahlan di
Kauman Yogyakarta tahaun 1912 kemudian mulai bergerak di Gresik tahun 1926 di rumah Abdul Chotib, dan (4) Persatuan Bangsa Indonesia yang mulanya adalah Indonesishce studieclub yang didirikan di Surabaya tahun 1924 oleh Soetomo yang juga pendiri organisasi Budi Oetomo (1908), tanggal 16 Oktober 1930 berganti menjadi PBI

- Lingkungan

Perang terus menerus berkecamuk di Jawa antara lain perlawanan Trunojoyo, Untung Suropati, Pangeran Singosari membuat Kartasura semakin lemah. Sebaliknya VOC semakin memperoleh keuntungan yang besar, karena setiap membantu Kartasura, VOC selalu memperoleh imbalan tanah dari Susuhunan Kartasura. Sebagai akibatnya daerah Kartasura makin sempit. Satu persatu wilayah Kartasura menjadi hak VOC, antara lain: Semarang, Bogor, Karawang, Preanger, bahkan di kota di wilayah Timur VOC semakin meluaskan wilayahnya dari Malang, Blitar, Besuki, Pasuruan, Lumajang, Lamongan, Pada Surabaya, Gresik, Sidayu, Tuban, sampai Bali. Pada tahun 1677 seluruh ujung Jawa Timur itu sudah masuk daerah VOC (Soekmono, 1973: 70). Kekuasaan VOC ini berlangsung terus Tengah, sampai pembubarannya tahun 1799 .

Selanjutnya semua utang itu diambil alih oleh pemerintah Belanda. Sejak itu pula wilayah Nusantara praktis menjadi wilayah jajahan Belanda, kecuali Bagelen, Kedu, Yogyakarta, dan Surakarta. Kekuasaan awal pemerintah Belanda di Nusantara dipegang oleh

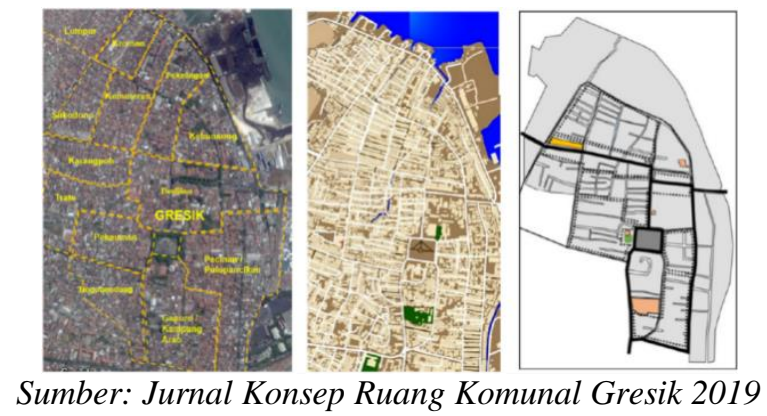

Gambar 10. Bentuk Permukiman Masa Kolonial 
Gubernur Jenderal Johannes Siberg (1801-1804), Jenderal Wiesel (18041808), dan Herman Wiliam Daendels sejak tahun 1808 sampai 1811 lebih ditekankan pada untuk perbaikan birokrasi pemerintahan, hukum dan

Tabel 6. Arkeologi Masa Kolonial

\begin{tabular}{clcl}
\hline No & Benda Arkeologi & Tahun & Keterangan \\
\hline 1 & Kantor Pos Bawean & 1930 & \\
\hline 2 & Kantor Pos Gresik & 1931 & \\
\hline 3 & Pompa Air Manyar & 1924 & \\
\hline Sumber: & Hasil Analisis 2019 & &
\end{tabular}

(1808-1811). Pemerintahan Hindia Belanda pada tahun 1801-1808 sekedar menjalankan politik lama yang dikembangkan oleh VOC. Sedangkan

4. Masa Pendudukan Militer Jepang

- Nama

Masa pendudukan Jepang di Gresik dimulai pada tahun 1934 setelah masa kolonialisasi Belanda dan Eropa hingga kurang lebih tahun 1953.

- Ciri Kota

Pada masa pendudukan Jepang di Indonesia, sebagian besar susunan pemerintahan masih mengikuti susunan pemerintahan Hindia Belanda, namun pembagian administrasi menurut propinsi (Gewest) dihapuskan, pembagian kini didasarkan pada hitungan syuu yaitu semaca residentie yang dipimping syuucokan dengan kedudukan sama dengan Gubernur. Pada tanggal 8 Agustus 1942 pulau Jawa dibagi dalam 17 Syuu (Bekas propinsi Jawa Timur pada waktu itu muncul syuusyuu, antara lain Surabaya, Bojonegoro, Madiun, Kediri Malang, Besuki, dan Madura. Gresik pada waktu itu masuk dalam wilayah Syuu Surabaya dipimpin oleh Syuucokan Yasuoka Masoemi. (Heru Sukadri K, et. al., 1984:2). Setelah berhasil meguasai Indoesia, Jepang mengadakan pemerasan terhadap ekonomi Indonesia. Untuk melaksanakan pemerasan ekonomi,Jepang membagi menjadi dua tahap, yaitu penguasaan dan penyusunan kembali ekonomi daerah jajahan untuk memenuhi kebutuhan bahan-bahan perang. (Hidayat et al., 2016) peradilan, ekonomi dan keuangan, serta militer dan pertahanan. (Ariestadi et al., 2016)

- Pusat Kota

Pada masa pendudukan Jepang, kota Gresik merupakan wilayah pertahanan strategis. Oleh karena itu bala tentara Jepang (Dai Nippon) berusaha membangun fasilitas pertahanan dengan mempekerjakan Romusha.

- Artefak

Pengerahan Romusha di Gresik diantaranya untuk membangun lapangan

pesawat terbang di Ngipik (sekarang menjadi kompleks pabrik Petrokomia Gresik) Proyek pembangunan lapangan pesawat terbang ini diberi nama Kubayasi. Tentara Jepang juga membangun galangan kapal di tepi Barat kota Gresik yang diberi nama proyek Nomura Tohindo Syukusan.

Proyek strategis lainnya adalah membangun gua-gua di lereng gunung kapur sebelah Selatan kota Gresik, yaitu gunung Petukangan dan di gunung kapur Desa Suci. Gua-gua ini diisi bom ukuran 25-200 kg, parasit-parasit, dan roti kabin untuk persiapan perang Asia Timur Raya. Ketika perang Asia Timur Raya berakhir dengan kekalahan di pihak Jepang di Gresik juga terjadi aksi pelucutan senjata. Tentara Jepang yang bermarkas di alon-alon Utara (sekarang gedung DPRD Gresik) diminta untuk menyerahkan senjata kepada para pejuang Gresik. Para juru runding dari Gresik waktu itu antara lain Syodanco R. 
Sunaryadi, Tamsi Tedjasasmita, Abdoellah Latif, Mochtar, Fakih Oesman, Basiran, dan Moch. Tam. (Ariestadi et al., 2016)

- Masyarakat

Untuk kepentingan perang Jepang membentuk badan. Adapun badan-badan yang terbentuk di Gresik pada masa pendudukan Jepang antara lain

- Jawa Hokokai (Gerakan Kebaktian Rakyat Jawa), dioleh Moesono. Kegiatan jawa Hokokai Gresik diantaranya: Mengirimkan kaderkadernya untuk mengikuti kursus di Jakarta yaitu S. Karnen dan Husin Asj'ari, Mengirimkan kursus kader gerakan olahraga ke Jakarta yaitu Ali Moeksin, Membentuk bagian perekonomian yang bertugas membagi makanan. Badan ini berkantor di Jl. Samanhudi Gresik, dikoordinasi oleh H. Anang Tajib dan Soedarno.

- Badan Pertimbangan Tenaga Rakyat, dikoordinasi oleh Tamsi Tedjasasmita bersama Fakih Usman dan Abdullah Fakih.

- Fujinkai (Persatuan Wanita), dipimpin oleh Ibu Moesono.

- Seinendan (Gabungan Pemuda, dipimpin oleh beberapa tokoh antara lain Muljono, Agus Adelan, Asjhari, Maskan, Dulasim, dan Dachlan Muchdor.

- Keibodan (Barisan Rakyat), dipimpin oleh H.Mochtar Ibrahim dan Abdullah Latif.

- Swisintai (Barisan Pelopor), dipimpin oleh Tamsi Tedjasasmita, Abdullah Umar, dan Chusnaeni. Kader-kader
Swisintai pernah dikirim ke Jakarta untuk mengikuti latihan peningkatan kemampuan fisik, antara lain Abdullah Azis, AK. Hudaya, dan Thoha Maksum.

- Badan Pembantu Prajurit bersamaan dengan pembentukan Peta, dikoordinasi oleh Tamsi Tedjasasmita, H. Noersyamsi, Maskun, dan H.M. Mas'ud. Tugas badan ini adalah penyerahan calon Peta, penyuluhan calon Peta, menghibur Peta, dan menghubungkan antara keluarga dengan Peta

- Badan Pembantu Prajurit Pekerja, dikoordinasi oleh Basiran dan Chusnaeni. (Abdul Wachid, 1984:814).

- Lingkungan

Dalam bidang budaya, Jepang berupaya agar budaya Barat dihapuskan. Karena itu, budaya Timur, termasuk budaya Indonesia boleh dihidupkan. Para pelajar di sekolah-sekolah diperintahkan untuk upacara. Dalam upacara tersebut dilakukan Seikerei, yaitu penghormatan kepada kaisar Jepang yang dianggap dewa, dengan cara menghadap ke Tokyo dan membungkukkan badan.

Di Gresik, Jepang membagi tugas pada sekolah-sekolah yang ada untuk melakukan kerja bakti (Kinrohoshi), Kerja bakti dilakukan secara bergilir untuk membersihkan markas bala tentara Jepang di pojok alon-alon Gresik (sekarang gedung DPRD Kabupaten Gresik) dan sekitarnya. (Mustakim, 2010)

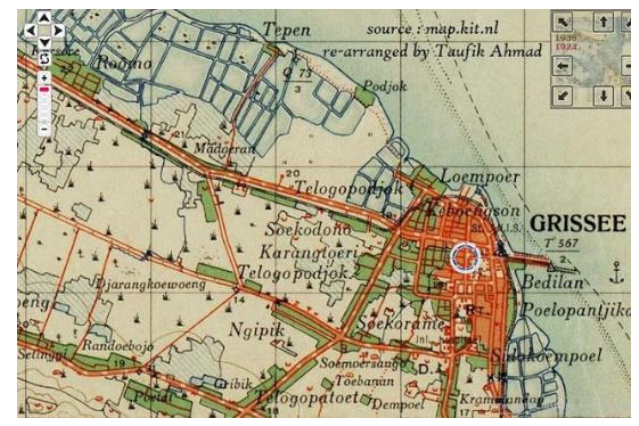

Sumber: Komunitas Pencinta Rel Kereta Api

Gambar 11. Gresik tahun 1924-1938 
Tabel 7. Benda Arkeologi Masa Pendudukan Jepang

\begin{tabular}{ll}
\multicolumn{1}{c}{ Benda Arkeologi } & \multicolumn{1}{c}{ Keterangan } \\
\hline Gedung DPRD (1984) & Pernah digunakkan sbg Markas Jepang \\
\hline Pabrik petrokimia Gresik & Dahulu lapangan Ngipik terbang (Kubayashi) hasil Romusha \\
\hline Galangan kapal & Bernama Proyek Nomura Tohindo Syukusan di Tepi barat Gresik \\
\hline Gua di lereng Gunung kapur Desa Suci & \\
\hline Gua di lereng Gunung Petukangan & Gunung di Sebelah selatan Kota untuk mengisi bahan Perang \\
\hline Sumber: Hasil Analisis 2019 &
\end{tabular}

5. Masa Awal Kemerdekaan

- Ciri Kota

Dari hasil survei disusun laporan berjudul "result of investigatoon by core drilling of the pliocebe limestone near Gresik" pada Januari 1951. Dalam laporan tersebut dijelaskan bahwa: dari bagian deposit yang disurvei itu saja telah menunjukkan adanya lapisan bahan galian yang dapat mencukupi persediaan untuk produksi sebuah pabrik semen selama 60 tahun dengan kapasitas produksi rata-rata 250.000 ton per tahun. Sebagai realisasi, pelaksanaan pembangunan pabrik semen Gresik tersebut oleh Pemerintah diserahkan kepada BIN (Bank Industri Negara). Selanjutnya dengan penugasan tersebut BIN mulai mengadakan persiapanpersiapan. (Mustakim, 2010)

Dalam hal ini BIN menyediakan pembiayaan lokal berupa rupiah sedang untuk pembiayaan valuta asing digunakan kredit dari Eximbank (Amerika Serikat). Pada tanggal 25 Maret 1953, dengan Akte Notaris Raden Meester Soewandi No. 41 di Jakarta, didirikanlah badan hukum N.V. Pabrik Semen Gresik, dengan Presiden Komisaris-nya: Bank Industri Negara, dan Direkturnya yang pertama Ir Ibrahim bin Pangeran Mohammad Zahier, pegawai tinggi Kementerian Perekonomian. Sebagai Konsultan untuk pelaksanaan pembangunan pabrik ini, pemerintah menggunakan jasa L.G. White dari Amerika Serikat. Sedang untuk penentuan lokasi dan pembuatan pola pabrik pemerintah mengkontrak konsultan untuk Kn MacDonald
Engineering Co. dari Amerika Serikat. Mereka datang pada tanggal 15

September 1953 di Gresik untuk mengadakan pemeriksaan setempat dan lebih intensif dilakukan hingga 1954. Pembangunan tahap pertama dari pabrik semen tersebut dimaksudkan untuk mendirikan sebuah pabrik semen yang memiliki 2 buah tanur pembakaran dengan jumlah kapasitas produksi 250.000 ton setiap tahun, dengan kemungkinan perluasan-perluasan di masa mendatang. Pemilihan kontraktor pelaksana proyek tersebut jatuh pada salah sebuah perusahaan pemborong yang terkemuka dari Amerika Serikat, yakni: Morrison Knudsen International Co., Inc. Pelaksanaan fisik pembangunan proyek ini dimulai bulan April 1955. Pembangunan ini dikerjakan lembur siang malam, dan akhirnya dapat rampung bahkan 73 hari lebih cepat dari deadline yang telah ditetapkan. - Grisee Tempoe Doeloe

- Artefak

Peninggalan benda cagar budaya pada masa awal kemerdekaan ini berupa Monumen Gunung Lengis yang merupakan Monumen yang menyimpan cerita dan benda sejarah mengenai pertempuran Gunung Lengis yang terjadi oleh pemuda Gresik dengan pemuda dari daerah lain di sekitar Gresik dalam rangka memperjuangkan kemerdekaan melawan penjajahan Belanda.

- Masyarakat

Menjelang detik-detik proklamasi kemerdekaan Indonesia, di Kota Surabaya dan sekitarnya telah ada gerakan-gerakan di tanah atau gerakan ilegal yang bertujuan untuk mencapai 
Indonesia merdeka. Gerakan dibawah tanah ini antara lain kelompok-kelompok pemuda yang bergerak di masing-masing organisasi pemuda pelajar buatan Jepang dan para pemuda jawatan pemerintahan atau swasta Jepang (Tim Penyusun, 1984: 52). Berita mengenai proklamasi kemerdekaan Ind onesia tanggal Agustus 1945 sejak tanggal 18 Agustus 1945 menyebar ke berbagai daerah di Indonesia. Beriringan dengan menyebarnya berita tentang proklamasi kemerdekaan, maka muncul serangkaian tanggapan dari tiap daerah. Misalnya di Surabaya tanggapan masyarakat terhadap proklamasi salah satunya dimanifestasikan dalam bentuk rapatrapat raksasa, juga berusaha untuk mempertahankan daerahnya serangan Sekutu yang ingin menguasai Indonesia. Peristiwa heroik ini mencapai puncaknya pada tanggal 10 November 1945 yang pada akhirnya diperingati sebagai hari pahlawan oleh seluruh bangsa Indonesia. Keberanian arek-arek Surabaya memotivasi para pejuang dari daerah lain, seperti Gresik, Jember, Situbondo, Bondowoso, sekitarnya. (Maulida \& Alrianingrum, 2015)

Setelah proklamasi kemerdekaan 17 Agustus 1945 dikuti instruksi untuk membentuk Komite Nasional Indonesia Pusat (KNI) pada tanggal 22 Agustus 1945. sebagai tindak lanjutnya, maka setiap daerah juga harus mendirikan Komite Nasional Indonesia (KNI) Daerah (A.G. Pringgodigdo, 1952: 24). KNI Kabupaten Surabaya di Gresik personalianya terdiri dari Tamsi Tedjasasmita, H. Anang Tajib, K.H. Fakih Oesman, Abdullah Fakih, dan Basiran. Kegiatan mereka dipusatkan di Jl. Basuki Rahmat no. 9 Gresik dan di rumah Liem Boen Kwie, JI. Basuki Rahmat no. 6 Gresik. (Hasil wawancara dengan Lettu Purn. H Shodig, tanggal 4 April 2007).

Diluar KNI terbentuk juga organisasi perlawanan pemuda yang tergabung dalam BKR dan PRI. Markas BKR menempati kantor telepon di Utara alonalon Kota Gresik. Para anggota BKR Gresik umumnya terdiri dari mantan Peta dan Heiho. Sebagai komandan BKR adalah Ibnoe Soebroto, kepala stafnya R. Soenarjadi, Doelasim, Soegondo, dan Markahim. Sementara itu untuk PRI pembentukannya dipelopori oleh $\mathrm{H}$ Mochtar Ibrahim. Abdoellah Latif, Noersyamsi, Maksum Asj'ari, Ali Moeksin, AK. Hudaya, Moeljono, dan Abdoel Azizs. Organisasi ini bermarkas di rumah Liem Hok Kiet (toko suling), Jl Basuki Rahmat no. 1 Gresik. Pada tanggal 5 Oktober 1945 BKR Kabupaten Gresik dilebur menjadi TKR Batalyon I Resimen II Divisi VI Gesik (Narutama). Sebagai komandan Batalyon Letkol Ibnoe Soebroto, 81. Wakil Mayor Moenawar Yasin, Kepala Staf Kapten Soenarjadi, Komandan Kompi I Kapten Soejoto, Komandan Kompi II Kapten Doelasim, Komandan Kompi III Kapten Darmosoegondo, Komandan Kompi IV Kapten Markahim, dan Komandan Pasukan Istimewa Letnan I Abdul Rachman. (Mustakim, 2006:96).

Dalam rangka mempertahankan kedaulatan Republik Indonesia, maka para pemimpin nasional di pusat melakukan upaya diplomasi terutama dengan Belanda yang sangat berambisi untuk kembali menguasai Indonesia. Hal ini menimbulkan ketegangan yang semakin memuncak antara kedua belah pihak yaitu Republik Indonesia dengan Belanda. Terlebih lagi Belanda secara terang-terangan meneruskan langkah untuk menguasai daerah Jawa dan Sumatra, padahal dalam perjanjian Linggajati telah mengakui secara de facto kekuasaan RI atas Jawa dan Sumatra. (M.C. Ricklefs, 1992:334). Bukti Kongkret keinginan Belanda menguasai RI, yaitu derngan dilancarkannya aksi militer pada Bulan Juli 1947. (Robert B. Cribh, 1990: 150).

- Lingkungan 
Pada tanggal 25 Oktober 1945 tentara Inggris, Brigade ke 49 dibawah pimpinan Brigjen A.W.S. Mallaby
Timur mendadak didatangi oleh dua orang perwira utusan A.W.S. Mallaby yang secara paksa mengundang R.M.
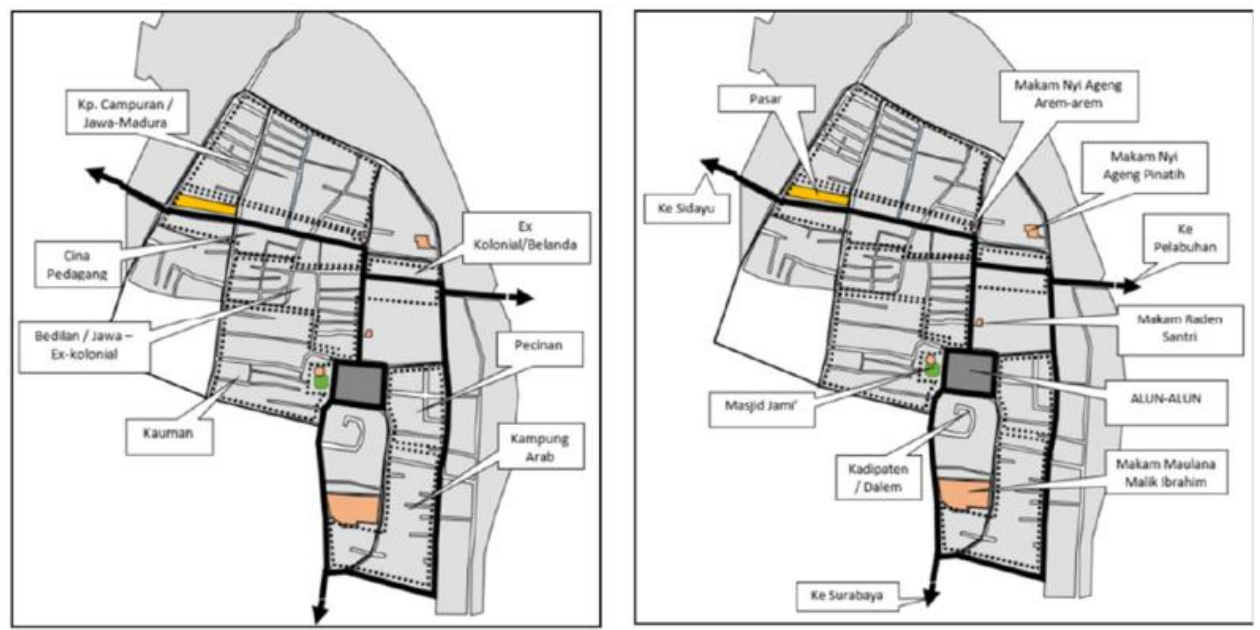

Sumber: Jurnal Ruang Komunal Gresik

Gambar 12 Bentuk Permukiman Masa Awal Kemerdekaan

mendarat di Tanjung Perak Surabaya. Dalam menanggapi tentara Inggris seorang tokoh Jawa Timur R.M.
Suryo untuk datang ke kapal perang mereka, namun ditolak. Esok harinya, tanggal 26 Oktober 1945 itu di Jl.

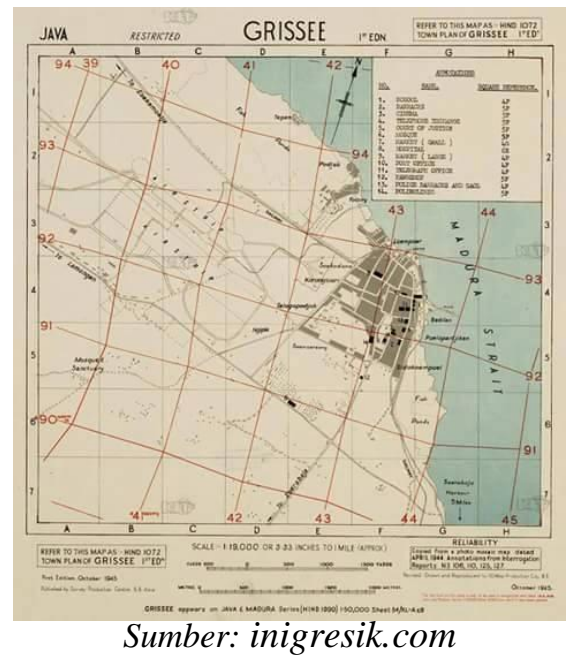

Gambar 12. Peta Grissee tahun 1945

Suryo bersikap tegas untuk mengatasinya dengan cara damai melalui perundingan. Pada hari itu pula ketika R.M. Suryo akan menghadiri rapat residen se-Jawa
Kayun terjadi peristiwa perundingan antara pimpinan tentara Inggris dan pimpinan RI, dengan keputusan antara lain: (1) Inggris hanya akan melucuti senjata tentara Jepanng, 
bukan TKR atau badan-badan perjuangan lainya. (2) Tentara Inggris selaku wakil dari Sekutu akan membantu dala $m$ pemeliharaan keamanan, ketertiban, dan perdamaian. (3) Setelah semua tentara Jepang dilucuti, maka mereka akan diangkut melalui laut.(Rouslan Abdoelgani, 1975:25)

Sesuai dengan hasil persetujuan tersebut, maka pada tanggal 27 Oktober 1945 pasukan Inggris diperkenankan menuju ke tempat-tempat interniran Belanda dan tempat tawanan Jepang. Namun berbagai provokasi dilakukan tentara Inggris diantaranya dengan sengaja menduduki lapangan terbang Tanjung Perak, Kantor Pos Besar, Gedung Internatio, BPM, Pusat Kereta Api, Pusat Otomobil, ANIEM (listrik) Gemblongan, Darmo, Gubeng, Ketabang, Sawahan, dan Bubutan. Pada waktu itu juga beberapa pesawat terbang Inggris menyebarkan selebaran yang memerintahkan penduduk kota Surabaya dan Jawa Timur untuk menyerahkan kembali semua senajata dan peralatan yang dirampas dari tentara Jepang kepada tentara Inggris. Semua orang yang kelihatan memegang senjata dan tidak menyerahkan kepada sekutu harus menanggung risiko untuk ditembak. (Tirn Penyusun, 1984: 106).

Sebagai tindak lanjut dari selebaran tersebut, pada tanggal 28 Oktober 1945 tentara Inggris mulai mencegati kendaraan-kendaraan yang dinaiki oleh pemuda-pemuda RI untuk dirampas kendaraan dan senjatanya. Aksi perampasan itu jelas sangat melukai hati pemerintah RI, rakyat, dan para pemuda pejuang. Lebih konyol lagi karena aksi tentara Inggris jelas sangat menodai isi perjanjian tanggal 27 Oktober 1945. Tindakan-tindakan konyol tentara Inggris tidak bisa dibiarkan oleh RI, maka untuk membela kehormatan bangsa berkobarlah pertempuran tanggal 28 s.d. 30 Oktober 1945. Pertempuran tersebut berakhir dengan adanya perundingan tingkat tinggi antara pihak RI yang dipimpin oleh Presiden Soekarno dan dan wakil presiden Moh. Hatta dengan pihak Inggris yang dipimpin oleh Mayor Jenderal Hawthorn dan Birgjend A.W.S Mallaby (Mustakim, 2010).

Perkembangan pada awal di Masa Kerajaan Majapahit dimulai dengan penduduk Kerajaan yang sebagian bermukim di daerah yang dekat pelabuhan atau Bandar yang cukup terkenal pada saitu yaitu Bandar Gresik dan Bandar Jaratan yang terletak di aliran Sungai Bengawan Solo dan Sungai Lamong. Sedayu saat itu masih merupakan daerah sendiri, berbeda dengan Gresik, selain itu Gresik pun sebgain pada bagian selatan masih dimiliki oleh Surabaya, sementara belum ada keterangan mengenai Pulau Bawean pada masa Majapahit. Kemudian pada masa penyebaran Islam kekuasaan Giri mulai terlihat dan perkembangan Islam semakin kuat sehingga Girimulai berkembang sendiri berbeda dengan Gresik yang sangat terkenal dengan Bandar atau pelabuhan transit internasional tersebut. Pada masa ini juga penduduk mulai menyebar sebagian besar pada Giri karena gerakan sosial pengaruh keagamaan (Islam) yang kuat. Giri dan Gresik pada saat itu menguasai karena pengaruh Islam dan dagang yang kuat, sementara Sedayu dan Bawean diketahui memiliki pemerintahannya sendiri. Kemudian karena banyaknya pendatang sebagai pengaruh Bandar yang terkenal, Gresik memiliki banyak pendatang dengana berbagai suku dan RAS yang kemudian untuk memudahkan pemerintahan, oleh Belanda pada masa Kolonial dibuat bermukin secara berkelompok berdasarkan asal usul tersebut sehingga tercipta perkampungan masyarakat. Pada masa Kolonial pula Sedayu dan Bawen menjadi satu Karesidenan Besar dengan Gresik. Selanjutnya pada masa pendudukan Jepang, permukiman penduduk ini semakin diperkuat keberadaan dan identitasnya oleh Jepang namun dengan system yang berbeda, Gresik termasuk di dalamnya Sedayu dan Bawean menjadi 
satu di bawah kepemimpinan Surabaya menjadi Syuu Surabaya. Hingga pada

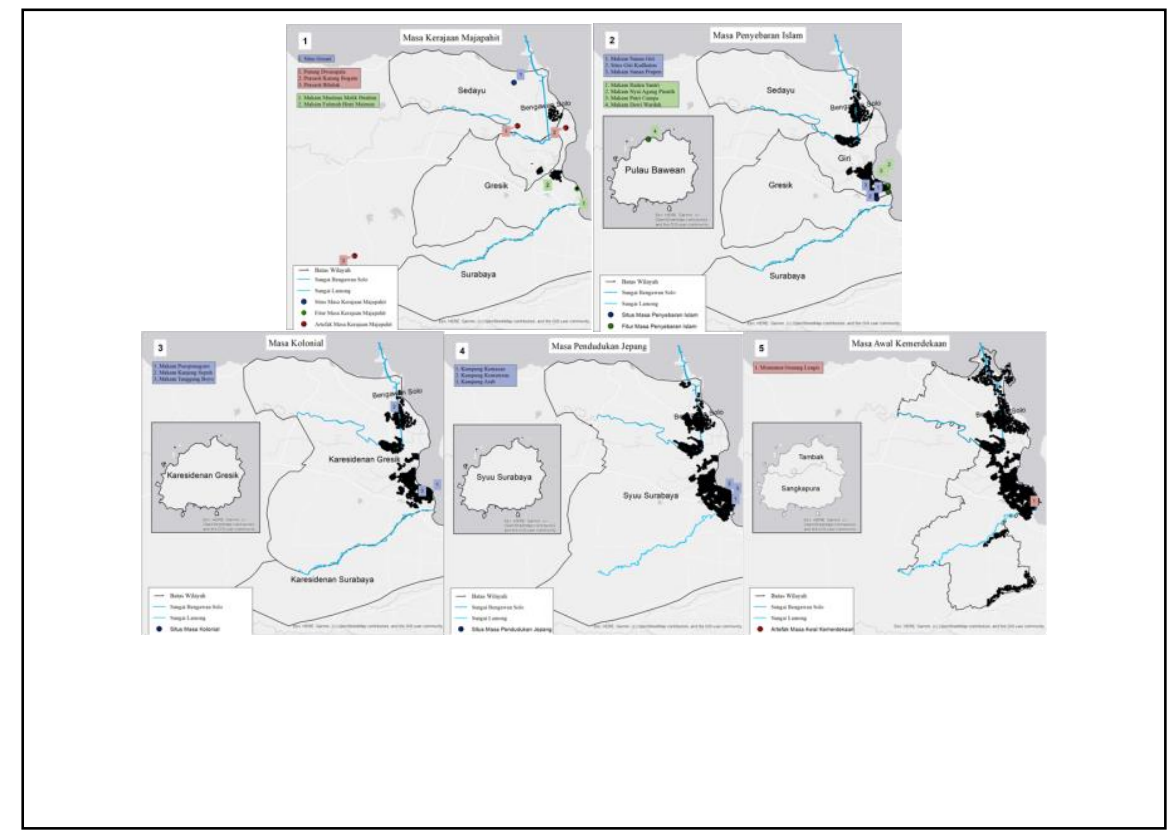

Sumber: Hasil Analisis, 2019

Gambar 13. Peta Time Series Stadia Perkembangan Kabupaten Gresik

akhirnya Gresik menjadi satu Kabupaten sendiri dengan Sedayu dan Pulau Bawen dengan beberapa bagian Surabaya bagian Barat yang saat ini mnejadi kawasan Industri. Tahapan perkembangan Kabupaten Gresik secara temporal digambarkan pada peta sebagai berikut (Gambar 13).

\section{KESIMPULAN}

Dari hasil studi literature, hipotesis dan kerangka stadia perkembangan kota dan triangulasi melalui in depth interview, ditemukan stadia perkembangan Kabupaten Gresik sebagai berikut:

- Masa Kerajaan Majapahit

- Masa Penyebaran Islam Nusantara

- Masa Kolonial

- Masa Pendudukan Jepang

- Masa Awal Kemerdekaan

Dengan periode waktu yang berpengaruh paling besar pada Masa Penyebaran Islam Nusantara

\section{UCAPAN TERIMAKASIH}

Penulis mengucapkan ucapan terima kasih kepada Badan Perencanaan Pembangunan, Penelitian dan Pengembangan Daerah Gresik, Dinas Pariwisata dan Kebudayaan Kabupaten Gresik yang telah memberikan datanya dan Institut Teknologi Sepuluh Nopember Surabaya.

\section{REFERENSI}

Ariestadi, D., Antariksa, Wulandari, L. D., \& Surjono. (2016). Konsep Courtyard Pada Permukiman Multi-Etnis Historis Di Kota Lama Gresik Sebagai Konsep Kearifan Lokal Berdasarkan Perspektif Post-Kolonial. Simposium Nasional RAPIXV.

Gandis Prameswari, A., Pendidikan Sejarah, J., \& Ilmu Sosial, F. (2013). PELABUHAN GRESIK PADA ABAD XIV Aminuddin Kasdi. In Journal Pendidikan Sejarah.

Gresik, D. P. dan K. (n.d.). Daftar Cagar Budaya Gresik. http://disparbud.gresikkab.go.id/

Hidayat, F. A. R. I., Sejarah, J. P., Ilmu, F., 
Gresik, P., Dagang, B., \& Lokal, P. (2016). Pergeseran Pelabuhan Gresik Dari Bandar Dagang Ke Pelabuhan Lokal Tahun 1484-1830. AVATARA, $e$ Journal Pendidikan Sejarah.

Hilmiyyah, D. R. (2019). Pelabuhan Gresik Sebagai Proses Perdagangan Islamisasi Abad XV-XVI M. Journal of Chemical Information and Modeling, 53(9), 16891699.

Jokiletho, J. (2008). The World Heriatge List: What is OUV? Defining the Outstanding Universal Value of Cultural World Heritage Properties. In Monuments and Sites edited by ICOMOS.

Kasdi, A. (2017). Kepurbakalaan Sunan Giri. UNESA University Press.

Kasdi, A., \& Sumarno. (2016). Babad Gresik. LPPM Unesa.

Mashuri, M. (2017). Kesejarahan Desa-Desa Pesisir dalam Serat Sindujoyo. Manuskripta. https://doi.org/10.33656/manuskripta.v7 i2.96

Maulida, R., \& Alrianingrum, S. (2015). Pabrik penayamakan kulit nv. kemasan keluarga h. oemar tahun 1898-1916 rizki maulida. AVATARA, e-Journal Pendidikan Sejarah.

Mustakim. (2005). Gresik sejarah Bandar Dagang dan Jejak Awal Islam Tinjauan Historis Abad XIII - XVII. Citraunggul Laksana.

Mustakim. (2010). Gresik dalam Lintasan Lima Zaman. Pustaka Eureka.

Mustakim. (2017). Satu Kota Tiga Zaman. Pustaka Media Guru.

Rahmawati, D., Suprihardjo, R., Santoso, E.
B., Setiawan, R. P., Pradinie, K., \& Yusuf, M. (2016). Penerapan Metode Rootcause Analysis (RCA) dalam Pengembangan Kawasan Wisata Cagar Budaya Kampung Kemasan, Gresik. Jurnal Penataan Ruang. https://doi.org/10.12962/j2716179x.v11i 1.5211

Supriharjo, R. (2013). Pelestarian Kawasan Cagar Budaya Kampung Kemasan Kabupaten Gresik sebagai Kawasan Heritage Tourism.

Supriharjo, R. (2016). Pelestarian Kawasan Cagar Budaya Kampung Kemasan Kabupaten Gresik sebagai Kawasan Heritage Tourism.

UNESCO. (2011). The HUL Guidebook, Managing Heritage in Dynamics and Constantly Changing Urban Environment. 15th World Conference of the League of Historical Cities.

UNESCO. (2013). Nafas baru kota bersejarah.

UNESCO World Heritage Centre. (2008). Operational Guidelines for the Implementation of the World Heritage Convention. Operational Guidelines for the Implementation of the World Heritage Convention.

Widodo, D. I., \& dkk. (2004). Grissee Tempoe Doeloe. Pemerintah Kabupaten Gresik.

Zainoeddin, O., \& dkk. (2013). Jelajah Gresik Kota Tua. Andhum Berkat. 